\title{
PROJECT MANAGEMENT AND MANAGEMENT OF INNOVATION IN SMALL INDUSTRIAL FIRMS
}

\author{
W.E. During \\ Department of Management Studies, Twente University of Technology, Enschede \\ (The Netherlands)
}

\begin{abstract}
In innovation projects, three sub-processes have to evolve concurrently. These are problem solving, to bring about a new product or process; internal innovation diffusion, to disseminate information and engender a positive attitude towards new developments; and change in the organization so that it may function successfully with new products or processes. The characteristics of these sub-processes and a need for special roles relating to them were suggested by a study of the innovation processes in small companies. A case history shows the possible use of the processes and roles indicated above to manage innovation projects.
\end{abstract}

\section{INTRODUCTION}

In the past $20 \mathrm{y}$ a lot has been written about project management and innovation management $[1-3]$. But the specific problems of small business, and the multi-project character of innovation, are relatively under-exposed in this body of literature. The present paper is meant to fill in part of the gap.

Several models have been developed for innovation processes and (technical) projects. In essence these are problem-solving models, in which activities are divided into several phases, based on decisions, types of activities, departments, etc. [4]. All models start with a problem or an idea and end with a solution or the use of a completed "product".

Innovation, however, is usually a multi-project process if we define it as: "the realisation of a new product-market-technology-combination". In small companies interaction between different projects and between projects and ongoing business is strong, in part because the same persons have responsibilities in both activities. This naturally creates specific problems for project management.

A study of innovation problems in small industrial firms revealed that the 
innovation process can be seen as a combination of three interrelated subprocesses, problem solving, internal innovation diffusion, and organizational change [5]. This model gives insight into some project management problems, and it is possible to formulate some conditions for the successful management of projects in terms of this model.

In section 2 both a short description of the innovation process and some specific roles that derive from the model we developed are given. Section 3 describes a case which illustrates the use of the model. Section 4 gives an analysis of the presented data, while section 5 formulates our conclusions.

\section{THE INNOVATION PROCESS AS THREE INTERRELATED PROCESSES}

\section{Problem solving}

In innovation we distinguish four types of innovation problems. In descending order of abstraction these range from determining a broad innovation strategy to, for instance, the introduction of newly developed products. The problem solving process may start at any of these problem stages and does not necessarily evolve in a logical order from one stage to the next. The process for solving these problems, however, is the same for all levels of abstraction. As a model for this process we use a clockwise cycle of four phases: 1 . the creative phase, 2 . the selection phase, 3 . the design phase and 4 . the application phase, see Fig. 1. This model was inspired by the "experiential learning model" of David Kolb for individual learning [7]. Typical activities for these phases are given in Table 1.

\section{TABLE 1}

Some characteristic activities of problem solving in innovation

Phase 4

Application

- application trials

- reporting of results

- training of users

- designation of resources

Phase 3

Design

- design of solution principle

- design of test programme

- design of operational and user specifications
Phase 1

Creative

- problem formulation

- analysis of information

- information gathering

- idea generating

- evolution of results

Phase 2

Selective

- draw specifications

- set priorities

- evaluate alternatives

- select alternatives 


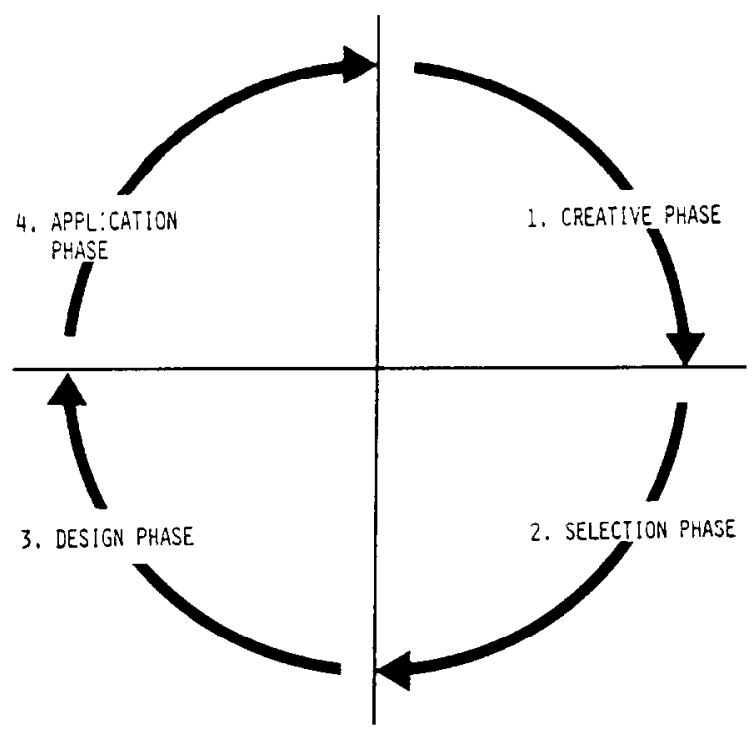

Fig. 1. Basic structure of the innovation process.

During innovation there is a lot of interaction between problem-solving activities. In the first place, a given innovation problem will be broken down into sub-problems. While solving these, the four phases of problem solving will not be synchronized for the different sub-problems. In the second place, after some time, new innovation problems will be added. And activities for solving the new problems will interact with the "older" problems. In the third place, activities for solving innovation problems and activities for the ongoing business will also interact, especially when the same people are engaged in both activities, as is frequently the case in small firms.

For activities during innovation several specific roles are identified in the literature. These include the idea generator, product champion, sponsor, project manager, and gate-keeper [6]. These roles do not cover all the characteristic activities observed in our study, where we distinguish two additional roles, those of integrator and scout.

\section{The integrator}

Because innovation is not a "single problem" process, balanced attention for different innovation problems is important. Achieving this balance is a task for the integrator. This role cannot be part of project management, which basically has responsibility for one project only.

The scout

For separate problems and ideas specific information has to be gathered. The role of a scout is a "directed" mission, namely to survey a specified, yet insufficiently known region. 


\section{Internal innovation diffusion}

During early problem definition, idea generating and prospecting, relatively few people are engaged in the innovation process. In later "phases" the number of people drawn into the innovation process increases. As a result, communication about and acceptance or rejection of problem definition, or ideas, is a continuous part of the innovation process. This process is very like the diffusion of innovation as regards innovations conceptualized outside an organization [2]. Mechanisms and models described in this diffusion of innovation literature are helpful for describing and analysing internal innovation diffusion even when there is no innovation as yet but only ideas or drafts.

Innovation diffusion consists of several distinct stages. In essence these comprise knowledge awareness, attitude formation, decision making, and implementation [2]. Since the last two stages are incorporated into the problem solving process, for internal diffusion we need only distinguish two phases, knowledge awareness and attitude formation.

Essential to knowledge awareness is the question of whether communication leads to "getting to know" the innovation idea. Diffusion at this stage is partly dependent on the ability to define innovation problems or innovation ideas precisely.

Also important is the information handling capacity. When people are overloaded with information, new information about an innovation will not be processed. In this situation, which seems very common in small firms, where ongoing activities take more time, the ability to handle innovationrelated information decreases.

During attitude formation, information about consequences is important. Resistance to change is an often-quoted mechanism in this phase. The actual behaviour of influential organization members is in this respect also very important [8]. Sometimes people express positive views on ideas or problems, but do not engage in the appropriate activities. Other people may interpret this behaviour as a negative attitude.

A specific role in innovation diffusion has been highlighted by our research. This is the role of the ambassador. The ambassador is seldom related to one particular idea or problem. He is important instead in two different communication streams. One of these originates with the problem-owner or problem-solver, and flows to people who will be engaged in the innovation process. The other stream originates with people who will be affected by the innovation process, and flows to the problem-owner or problem-solver. This flow affects actual attitudes in regard to the ideas or problems under consideration. The ambassador will pass on information and will suggest changes in the communication or problem-solving process. 


\section{Organizational change}

On the subject of change in the organization we do not mean organization development, a phenomenon that is generally seen as restricted to social interaction. Change in the organization in connection with innovation may be related to all parts of the organization. Taking the organization as "an organized whole of people and resources trying to attain certain goals" we see as the components of organization: people, resources, processes, and regulations. Change in the organization can take place with regard to any or all of these parts, and there is a further distinction between quantitative and qualitative change.

In the innovation process we can distinguish two categories of organizational change, change to facilitate problem solving, and internal diffusion or change as a result of problem solving.

No specific roles are mentioned in the innovation literature with regard to organizational change. For this reason we designate the role of (re)organizer. In this way we draw explicit attention to organizational change as a possible condition for successful innovation. The (re)organizer has to play a role in initiating, realizing and consolidating change in the organization (adapted from [9]). Remember that we define organizational change as change in any of the constituent parts of the organization (people, resources, processes and regulation).

\section{CASE DESCRIPTION}

We will demonstrate the possible use of the model presented in section 2 with a case description. "Medical Products" is a company with a workforce of about 200 people. It produces consumer goods both for the consumer market and for professional users in the Netherlands. Product development is generally initiated by a special request from a customer. Part of the production system is out of date, and recently competition is growing from companies with a more modern market approach.

\section{Problem solving}

An innovation group will develop an innovation strategy for the professional market. This market was chosen because competitive pressure was growing and because it had possible potential for profitable, high value products. The financial goal was to increase sales by $50 \%$ within $3 \mathrm{y}$, maintaining the net result as a percentage of sales.

After several meetings the problem definition was formulated as:

1. Develop a more professional way of dealing with professional customers.

Develop products or services in line with the new approach. 
2. Develop new activities by using new materials.

3. Extend trading activities in present markets.

4. Strengthen the competitive position by new production technologies.

Some important activities in further defining the innovation goals are shown in Fig. 2 for the four phases of problem solving.

Based on a general description of possible innovation strategies, ideas for the product-market-technology combination are generated (1). Next, information is sought to test the feasibility of the ideas and to develop ideas into propositions (2). Two propositions are selected for further development (3). For one of these propositions more information about the operational processes of a specified user-category is needed. An in-depth study with user organizations is planned (4). For realization of the propositions a legal permit for the distribution of pharmaceutical products must be acquired (5). Some group-members propose a change in the organization of the operational activities of the firm. In dealing with professionals, the organization should itself act more professionally (6). A study within some user organizations gives more insight into their operating processes (7). This information will be used to generate new ideas for professional products and services. The necessity for a legal permit is again underlined. It becomes clear that for

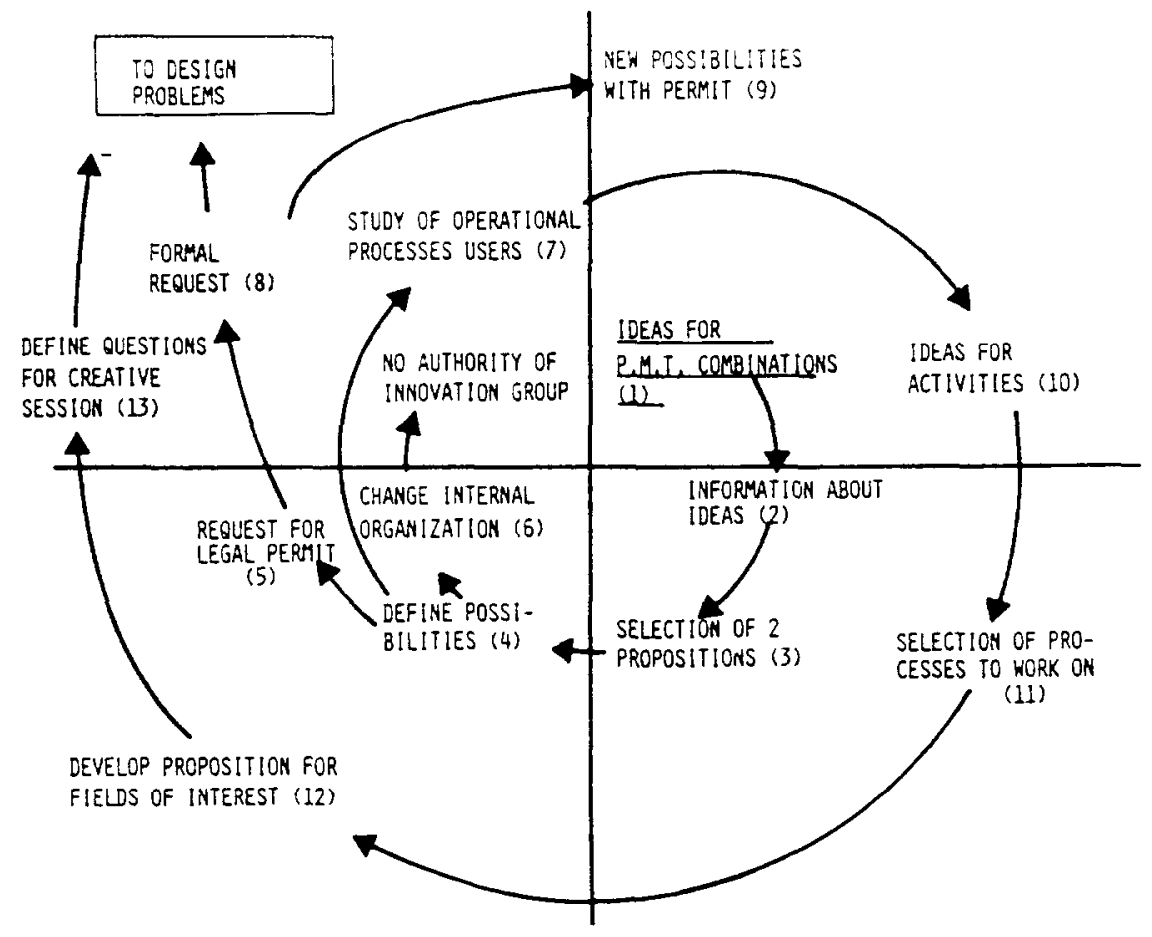

Fig. 2. Some important activities for defining innovation goals. 
about $1 / 2$ y no action to obtain the permit has been taken. As a result promises to customers to deliver test-samples of new products cannot be kept. When customers start to turn to other firms the request for a permit is presented to the authorities (8).

Major reasons given for omitting to request a permit were:

1. the activities of group members and others focussed on the introduction of new packaging for all products;

2. the opinion that it would be impossible to acquire the permit;

3. the change in workload for the sales department (phase 4).

\section{Internal innovation diffusion}

The entire group engages in a brainstorming session on additional market opportunities for the firm once the permit is available (9). While waiting for the permit, a few members of the innovation group make preparations for a "creativity-session" with outside experts (10-13).

\section{Organizational change}

Organizational changes related to the example given are installations and training of the innovation group, appointment of an employee to execute actions decided upon in the innovation group, the required change in the organization of operational activities and the acquisition of a legal permit. The kind of change is summarized in Fig. 3.

Part of the organization affected by change

\begin{tabular}{|c|c|c|c|c|c|}
\hline \multirow[t]{2}{*}{ Type of change } & \multirow[t]{2}{*}{ People } & \multirow[t]{2}{*}{ Resources } & \multirow[t]{2}{*}{ Processes } & \multicolumn{2}{|c|}{ Regulations } \\
\hline & & & & Internal & External \\
\hline $\begin{array}{l}\text { 1. Innovation } \\
\text { group }\end{array}$ & 0 & & 0 & 0 & \\
\hline $\begin{array}{l}\text { 2. Innovation } \\
\text { employee }\end{array}$ & to & & & 0 & \\
\hline $\begin{array}{l}\text { 3. Control of } \\
\text { operations }\end{array}$ & & & 0 & 0 & 0 \\
\hline 4. Legal permit & & to & 0 & & \\
\hline
\end{tabular}

Fig. 3. Organizational change as part of the innovation process. $\circ=$ a qualitative change, $+=\mathrm{a}$ quantitative change. 


\section{DISCUSSION}

The innovation process of "medical products" gives a clear demonstration of the interacting processes of problem solving, internal innovation diffusion, and organizational change.

All the sub-processes form an important part of the problem of "professionalizing". For the other innovation problems, at least two of the subprocesses are important as is shown in Fig. 4.

\begin{tabular}{llll} 
& Problem solving & Organizational change & Internal diffusion \\
\hline Professional & + & + & + \\
New materials & + & - & 0 \\
Extend trading & + & 0 & - \\
New technology & + & + & 0 \\
\hline
\end{tabular}

Fig. 4. Importance of problem solving, organizational change and internal diffusion for four innovation problems. $+=$ very important, $0=$ important, $-=$ unimportant.

An analysis of the composition of the innovation group in relation to the sub-processes gives an explanation of why management of these innovation projects was so difficult, see Fig. 5 .

\begin{tabular}{|c|c|c|c|}
\hline & $\begin{array}{l}\text { Problem } \\
\text { solving }\end{array}$ & $\begin{array}{l}\text { Organizational } \\
\text { change }\end{array}$ & $\begin{array}{l}\text { Internal } \\
\text { diffusion }\end{array}$ \\
\hline Salesman & $\begin{array}{l}\text { knowledge } \\
\text { professional } \\
\text { market }\end{array}$ & $\begin{array}{l}\text { no formal } \\
\text { position }\end{array}$ & $\begin{array}{l}\text { often outside } \\
\text { the organization }\end{array}$ \\
\hline Sales manager & $\begin{array}{l}\text { knowledge } \\
\text { consumer } \\
\text { market }\end{array}$ & $\begin{array}{l}\text { formal position } \\
\text { for his group }\end{array}$ & $\begin{array}{l}\text { often inside } \\
\text { the organization }\end{array}$ \\
\hline Works manager & $\begin{array}{l}\text { knowledge } \\
\text { of technology }\end{array}$ & $\begin{array}{l}\text { formal position } \\
\text { for production }\end{array}$ & $\begin{array}{l}\text { often inside } \\
\text { the organization }\end{array}$ \\
\hline "Innovation man" & $\begin{array}{l}\text { no specific } \\
\text { knowledge }\end{array}$ & $\begin{array}{l}\text { no formal } \\
\text { position }\end{array}$ & $\begin{array}{l}\text { usually inside the } \\
\text { organization }\end{array}$ \\
\hline Managing director & $\begin{array}{l}\text { knowledge of } \\
\text { general trends }\end{array}$ & $\begin{array}{l}\text { formal position } \\
\text { for the organization } \\
\text { as a whole }\end{array}$ & $\begin{array}{l}\text { inside the } \\
\text { organization }\end{array}$ \\
\hline
\end{tabular}

Fig. 5. Composition of the innovation group, denoting ability to participate in the subprocesses of innovation. 
For problem solving, knowledge of the market, technology, and general developments in the industry are incorporated in the group. Know-how and experience is sufficient for solving concrete problems. But most group members have no experience with more general and strategic problem solving.

The capacity for the scouting role is insufficient. All except one of the group members are primarily responsible for current operations. This is especially true of the salesman for the professional market, who has not got enough time to gather information on either the applications or specifications for new products.

The managing director is at least in theory in a position to fulfill the integrator role. Yet because he tends to stress urgent operational problems, coordination of the innovation activities of different group members remains insufficient.

For internal innovation diffusion, the capacity to communicate with and influence the attitude of the sales department is not enough. The salesman who really is the "product-champion" is seldom "in house", the department is not overly enthousiastic about innovation, and the director puts the consumer market first. The ambassador role is sufficiently played for the production department by the works manager, and for the consumer products department by the sales manager. For the professional products department the ambassador role is not fulfilled, and as a result there is insufficient action to influence the attitude of this department.

The necessary authority for organizational change is incorporated in the innovation group. Bottlenecks for realizing necessary changes are related to accepting the necessity for the consequences of proposed changes. It also proves to be difficult to hire the right people for tasks that are new to the organization.

The role of (re)organizer is seldom fulfilled.

\section{CONCLUSIONS}

An organization dealing with innovation projects has to control three simultaneous processes. For each process some particular roles are needed. Characteristics of a given organization and of the three processes determine the kind of bottlenecks the organization will meet within the course of innovation projects, see Fig. 6.

Based on this model of innovation some guidelines can be formulated for the management of innovation projects.

1. When forming a project team it is not sufficient to select people for their abilities in the problem solving process. For a particular project the relative importance of problem solving, internal diffusion and organizational change must be determined. As far as possible members of the project team must be sclected so that the crucial activities of the three processes can be executed. Supplementary actions will be needed in most instances. With "Medical Products" for instance a special task force was created to 


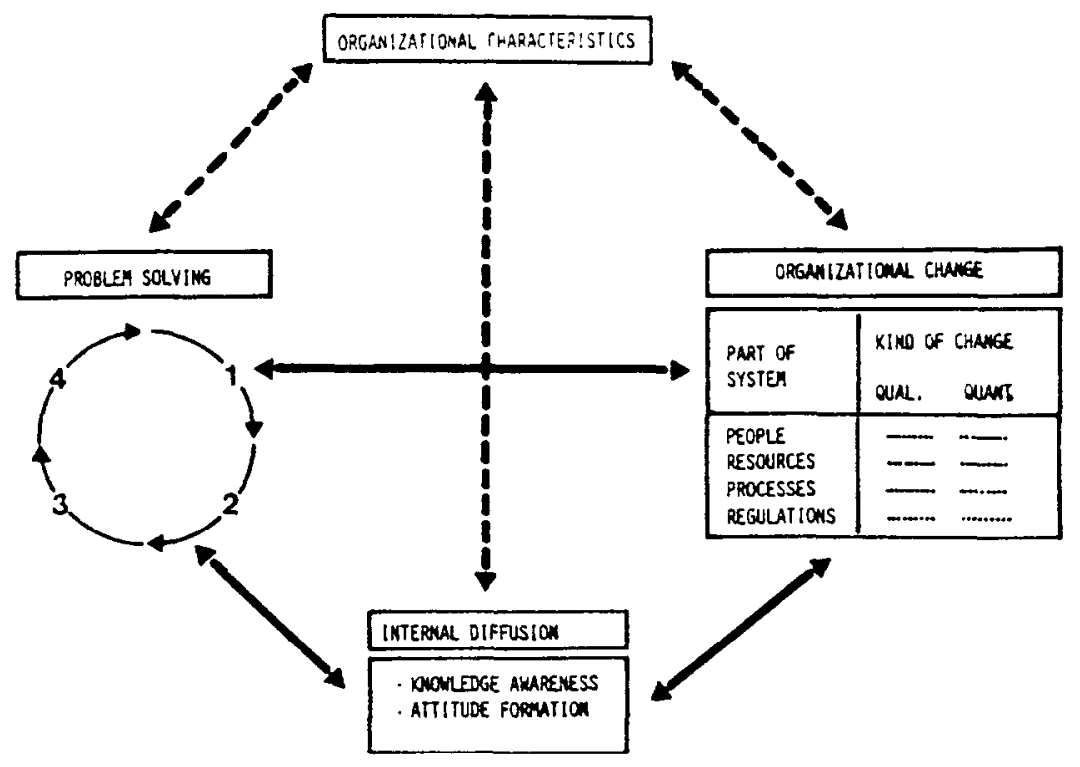

Fig. 6. Relation between sub-processes of innovation and organizational characteristics.

involve the professional products department in the development of new activities (internal diffusion).

2. Fulfillment of specific roles is crucial to the success of innovation projects. One has to ensure that these roles are covered by the people engaged in the innovation process. The scouting role may be contracted out to people outside the organization. In this case the internal diffusion process needs extra attention. The other roles, integrator, reorganizer and ambassador have to be played by the organziation's members.

\section{REFERENCES}

1 Kelly, P. and Kranzberg, M. (Eds.), 1975. Technological Innovation: A Critical Review of Current Knowledge, Vols. 1 \& 2, N.T.I.S., Atlanta/GA.

2 Rogers, E.M., 1983. Diffusion of Innovations, 3rd Ed. The Free Press, New York.

3 Kerzner, H., 1979. Project Management, A System Approach to Planning, Scheduling and Controlling, Van Nostrand Reinhold Company, New York.

4 Saren, M.A., 1984. Classification and review of models of the intra-firm innovation process, $R$ \& D Management, 14 (1) pp. 11-24.

5 During, W.E., 1984. Innovatieproblematiek in kleine industriële bedrijven, Ph.D. Thesis, Department of Management Studies, TH Twente.

6 Roberts, E.B. and Fusfeld, A.R., 1981. Staffing the innovative technology-based organization. Sloan Management Review, 3, pp. 19-34.

7 Kolb, D.A., Rubin, I.M. and McIntyre, J.M., 1974. Organizational Psychology: An Experimental Approach, 2nd Ed. Prentice Hall, New York.

8 Davis, T.R.V. and Luthans, F., 1980. A social learning approach to organizational behavior. Academy of Management Review, 5 (2) pp. 281-290.

9 Lewin, K., 1958. Group Decision and Social Change. In: E.E. Maccoby, T.M. Newcomb and E.L. Hartley (Eds.), Readings in Social Psychology, Holt, Rhinehart and Winston, New York, pp. 197-221. 